\title{
PENGARUH PEMBERIAN PANGAN FORTIFIKASI ZAT MULTI GIZI MIKRO PADA IBU HAMIL TERHADAP PERTUMBUHAN LINIER, TINGGI LUTUT DAN STATUS ANEMIA BAYI
}

\author{
Bernatal Saragih ${ }^{1}$; Hidayat Syarief ${ }^{2}$ Hadi Riyadi ${ }^{2}$ dan Amini Nasoetion ${ }^{2}$ \\ ${ }^{1}$ Mahasiswa Program Doktor GMK IPB dan Dosen Fakultas Pertanian Unmul \\ ${ }^{2}$ Dosen Fakultas Ekologi Manusia Institut Pertanian Bogor
}

\section{ABSTRACT \\ EFFECT OF MULTI MICRONUTRIENTS FORTIFIED SUPPLEMENTARY FOOD IN PREGNANT WOMEN ON LINEAR GROWTH, KNEE HEIGHT AND ANEMIA STATUS OF INFANTS}

Like in many developing countries, macro and micro nutritional deficiencies are the serious problem, especially for Indonesian pregnant women and young age children. Early nutritional intervention strategy through supplementary fortified foods for pregnant women is one of alternative nutritional improvement interventions for the next generation.

The objective of this study is to analize the impact of multi micronutrients fortified supplementary food in pregnant mothers on linear growth, knee height and anemia status of infants. This study was conducted in three sub-districts of Bogor Distritcs namely: Leuwiliang, Leuwisadeng and Ciampea. This prospective cohort study follow up 120 infants. The total of infants has been followed up was 120 . From 120 born infants, 40 infants were selected as a fortified group in which their mothers during pregnancy received fortified food (consists of vermicelli, milk and biscuit with multi-nutrients i.e. iron, iodine, zinc, folic acid, vitamin $C$ and vitamin A), 40 infants as unfortified groups in which their mothers was received non fortified foods, and 40 infants as control groups (their mothers did not receive any experiment food). Data analyzed using SPSS 13.0. Z-score were calculated for the length-for-age (HAZ) of WHO 2006 growth reference.

The result of study showed that multi micronutrients fortified supplementary food for pregnant mothers had significant effect on infants linear growth which was $2.18 \mathrm{~cm}$ taller compared to control group and $1.53 \mathrm{~cm}$ taller compared to unfortified group. The mean of liniear growth and HAZ fortified group up to 6 months infants was better than unfortified and control. Earlier complementary food intoduction were associated with the decrease of infants' linear growth and HAZ. Stunting (5.0\%) was found at two months of infants' age in control group. Fortified food supplementation for pregnant women had significant effect on infant knee height gain. Infant knee height $(\leq 14.248 \mathrm{~cm})$ at 6 months was categorized as stunting. Multi micronutrients fortified supplementary food in pregnant mother had an retention effect of decreased infants $\mathrm{Hb}$ at up to 6 months.

Keywords: Multi micronutrients, pregnancy, infant, breast feeding, linear growth, knee height, hemoglobin

\section{PENDAHULUAN}

K esehatan dan gizi ibu hamil merupakan kondisi yang sangat diperlukan bagi janin untuk menjadi sehat. Jika tidak, maka dari awal kehidupan manusia akan bermasalah pada kehidupan selanjutnya. Masa kehamilan merupakan periode yang sangat menentukan kualitas anak yang dilahirkan. Keadaan gizi ibu yang kurang baik sebelum hamil dan pada waktu hamil cenderung untuk melahirkan bayi dengan BBLR, bahkan kemungkinan bayi meninggal dunia. Anak yang dilahirkan 
dengan berat badan rendah berpotensi menjadi anak dengan gizi kurang bahkan menjadi buruk ${ }^{(1)}$. Gizi buruk pada anak balita berdampak pada penurunan tingkat kecerdasan atau IQ. Lebih jauh lagi dampak yang diakibatkan adalah meningkatnya kejadian kesakitan bahkan kematian ${ }^{(2)}$.

Hasil berbagai penelitian menunjukkan usia penyimpangan pertumbuhan setelah lahir menunjukkan variasi yang berbeda, dapat terjadi sejak usia sebulan ${ }^{(3)}$, dua bulan (4) dan pada usia 6-7 bulan setelah dilahirkan ${ }^{(5)}$. Suplementasi multi gizi lebih responsif terhadap pertambahan tinggi lutut dibandingkan suplemetasi mineral tunggal(33).

Masalah anemia di berbagai negara sedang berkembang juga sangat tinggi. Anemia pada bayi akan mengganggu pertumbuhan dan perkembangannya. Di Indonesia prevalensi anemia usia 6 bulan mencapai 61 persen dan meningkat 65 persen pada usia 12 bulan dan 31 persen pada balita kurang gizi (-2 Z-score berat/umur) $)^{(6)}$. Bayi yang diberi ASI eksklusif lebih dari 6 bulan memiliki $\mathrm{Hb}$ yang lebih rendah dibandingkan dengan mereka dengan ASI 4-6 bulan, yang diukur pada umur 9 bulan $^{(7)}$.

Ada keraguan tentang pola pertumbuhan bayi pada 6 bulan pertama kehidupan, juga tentang kecukupan zat gizi. Jarang dilakukan penelitian longitudinal tentang pertumbuhan dan pemberian ASI pada bayi sehat. Banyak penelitian hanya membandingkan antara masyarakat industri dan masyarakat berkembang berkaitan dengan ibu yang mengalami kekurangan gizi akan memproduksi ASI lebih sedikit, dan tidak dikaitkan dengan pertumbuhan bayi. Dari segi gizi, antibodi dan psikososial ASI, mempunyai peran penting terhadap pertumbuhan dan perkembangan anak. Hasil penelitian menunjukkan bahwa suplementasi zat gizi selama kehamilan berpengaruh terhadap komposisi zat gizi ASI dan pertumbuhan bayi $i^{(8,9,10,11)}$. Lamanya pemberian ASI berhubungan dengan pertumbuhan panjang badan terutama pada anak usia dibawah tiga tahun ${ }^{(12,13,14)}$ dan ponderal indeks bayi 0-6 bulan ${ }^{(15)}$.
Gizi selama kehamilan juga sangat erat kaitannya dengan hasil kelahiran dan laktasi. Salah satu alternatif memotong siklus hayati kekurangan gizi jatuh pada mata rantai status gizi dan kesehatan ibu hamil yang merupakan faktor penentu kesehatan dan gizi generasi selanjutnya. Intervensi gizi pada masa kehamilan dapat memperbaiki komposisi dan ukuran tubuh pada masa remaja dan dewasa kelak. Pemberian makanan tambahan (PMT) pada ibu hamil adalah salah satu alternatif perbaikan gizi bagi generasi berikutnya. Hasil meta analisis PMT antara energi-protein yang seimbang (300-800 kkal/hari) dan energi yang berasal dari protein di bawah 25 persen dapat meningkatkan tambahan berat badan pada ibu hamil terutama pada ibu yang mengalami kurang energi kronik (KEK), pertumbuhan janin dan ukuran bayi yang dilahirkan ${ }^{(16)}$. Sebaliknya PMT yang tinggi protein >25 persen dapat memberikan efek sebaliknya, penurunan pertambahan berat badan dan berat bayi yang dilahirkan. Hasil penelitian di Bangladesh menunjukkan bahwa ibu yang pada waktu hamil diberikan supplementasi makanan 608 kkal per hari selama 4 bulan dapat meningkatkan berat bayi lahir $118 \mathrm{~g}^{(17)}$.

Pada tahun 2005-2006 SEAFAST IPB, melakukan studi mengenai "Pengaruh Pemberian Pangan yang Difortifikasi Zat Multi Gizi Mikro Terhadap Status Gizi Ibu Hamil dan Berat Bayi Lahir". Zat gizi yang digunakan sebagai fortifikan adalah asam folat, vitamin $A$, vitamin $C$, besi, iodium dan seng. Studi ini dilakukan pada ibu hamil trimester dua sampai melahirkan. Penelitian ini mengacu pada keseimbangan energiprotein. Berbagai penelitian menunjukkan dampak positif dari pemberian makanan tambahan yang difortifikasi zat gizi. Studi di India menunjukkan perbaikan pertumbuhan linier signifikan setelah 14 bulan pemberian makanan tambahan ${ }^{(18)}$. Di Jamaica tinggi badan signifikan setelah pemberian makanan tambahan 12 bulan. Pengaruh suplementasi makanan secara kumulatif tidak terjadi pada 6 bulan pertama ${ }^{(19)}$. Sehingga pemberian pangan fortifikasi pada ibu selama 6 bulan dalam penelitian tersebut tidak memberikan pengaruh yang berbeda 
nyata terhadap hasil kelahiran. Oleh karena itu dampak lanjutan PMT tersebut merupakan suatu kajian penelitian yang menarik. Intervensi gizi pada masa kehamilan juga dapat memberikan tambahan atau simpanan zat gizi yang lebih baik pada ibu dan janin, misalnya intervensi besi dapat meningkatkan simpanan besi dalam bentuk ferritin atau haemosiderin dalam hati dan darah, seng dalam bentuk $\alpha$-macroglobulin, asam folat dalam bentuk poliglutamat, dan iodium dalam tiroid dalam bentuk tiroglobulin. Simpanan ini dapat dimanfaatkan bayi dari ASI selama masa menyusui misalnya laktoferin. Demikian juga halnya dengan zat gizi yang pro pertumbuhan seperti seng, yodium, vitamin $A$ dan folat diduga memungkinkan meningkatkan cadanganya pada bayi yang dilahirkan.

\section{BAHAN DAN CARA}

Penelitian ini dilaksanakan di 21 desa, terletak di Kecamatan Leuwiliang, Ciampea dan Leuwisadeng, Kabupaten Bogor, Propinsi Jawa Barat. Penentuan lokasi didasarkan bahwa Jawa Barat memiliki angka kematian ibu 321 per 100.000 kelahiran hidup ${ }^{(20)}$. Selanjutnya penentuan lokasi kecamatan didasarkan pada pertimbangan kemudahan teknis di lapangan dan adanya kerjasama yang baik dari pihak pemerintah daerah setempat (kecamatan) dan juga Puskesmas. Partisipan penelitian adalah bayi yang dilahirkan dari ibu yang pada waktu hamil ikut program feeding dan non feeding selama 6 bulan yang telah dipublikasi dengan judul Pengaruh Pemberian Pangan yang Difortifikasi Zat Multi Gizi Mikro Terhadap Status Gizi Ibu Hamil dan Berat Bayi Lahir ${ }^{(1,2)}$. Kelompok perlakuan adalah ibu yang mendapat intervensi biskuit, bihun dan susu yang difortifikasi dengan vitamin $A$, vitamin $C$, asam folat, besi, seng dan iodium, dan kelompok yang mendapat biskuit, bihun dan susu yang tidak difortifikasi, serta kelompok tanpa menerima makanan tambahan (Kontrol).
Kriteria inklusi adalah bayi tidak sakit serius (tidak memiliki penyakit jantung, ginjal serta kelainan organ tubuh lainnya), berat badan lahir $\geq 2500$ gram (normal), tidak kembar dan lahir dengan cara normal. Sedangkan kriteria ibu hamil yang digunakan pada penelitian sebelumnya adalah berusia 18-35 tahun, usia kehamilan 2-3 bulan, bukan kehamilan pertama atau di atas kehamilan kelima, sehat, tidak merokok dan tidak minum alkohol, tidak memiliki penyakit kronik, dan bersedia mengikuti kegiatan penelitian lanjutan dengan umur bayi 0-6 bulan. Ibu yang sudah melahirkan dilakukan pendataan ulang dan ditanyakan kesediaannya (informed consent) untuk mengikuti penelitian lanjutan terhadap pertumbuhan, perkembangan motorik, dan status anemia bayi yang diikuti secara kohort 0-6 bulan. Dari hasil pendataan ulang, dari 165 bayi yang memenuhi kriteria adalah 120 orang, sehingga untuk masing-masing perlakuan 40 orang.

Panjang badan bayi, tinggi lutut, morbiditas, status pemberian ASI, pengasuhan diamati setiap bulan sampai umur 6 bulan serta hemoglobin dan hematokrit bayi di ukur pada usia 6 bulan. Penelitian ini memperoleh ethical clereance dari Komisi Etik Badan Penelitian dan Pengembangan Kesehatan, serta persetujuan (informed consent) juga diperolah dari partisipan secara. Pengolahan data dilakukan menggunakan program SPSS versi 13.0. Z-skor PB/U dianalisis dengan menggunakan rujukan baku WHO 2006 .

\section{HASIL}

Pertumbuhan adalah salah satu indikator untuk menilai kecukupan gizi bayi yang berdampak terhadap aspek fisik. Berat badan menurut umur dan panjang badan menurut umur merupakan pengukuran antropometri yang digunakan sebagai penilaian pertumbuhan fisik. Hasil pengukuran yang dibandingkan dengan rujukan antropometri WHO 2006 merupakan proses untuk menilai diagram pertumbuhan ${ }^{(21,22)}$. 
Pertumbuhan linier diamati berdasarkan selisih/pertambahan panjang badan $(\Delta \mathrm{PB})$ dari mulai lahir sampai 6 bulan. Hasil uji Ancova menunjukkan adanya perbedaan yang nyata $(p<0,05)$ antara kelompok perlakuan. Panjang badan pada umur 6 bulan dan pertambahan panjang badan tertinggi diperoleh pada kelompok fortifikasi yaitu $17,94 \mathrm{~cm}$, kemudian kelompok tanpa fortifikasi $16,41 \mathrm{~cm}$ dan terendah pada kelompok kontrol yaitu 15,76 cm (Tabel 1).

Selisih pertambahan panjang badan antara kelompok fortifikasi dengan kelompok tanpa fortifikasi sebesar $1,53 \mathrm{~cm}$, dan dengan kelompok kontrol sebesar 2,18 cm. Sedangkan selisih pertambahan panjang badan antara kelompok tanpa fortifikasi dengan kelompok kontrol sebesar $0,65 \mathrm{~cm}$. Jika dibandingkan dengan rujukan baku WHO 2006, terlihat pola pertambahan panjang badan bayi perempuan pada 6 bulan pertama kelompok fortifikasi dan tanpa fortifikasi hampir sama dengan rujukan tersebut (Gambar 1). Sedangkan kelompok kontrol mulai pada umur 2 bulan terjadi penyimpangan terhadap kurva rujukan. Dengan semakin bertambahnya usia bayi pada kelompok kontrol, penyimpangan tersebut semakin besar juga. Pada usia 6 bulan selisih panjang badan bayi kelompok kontrol dengan rujukan WHO 2006 adalah $2,1 \mathrm{~cm}$.

Pola yang sama juga terjadi pada kelompok kontrol untuk bayi laki-laki penyimpangan pertumbuhan semakin besar dari kurva referensi dengan semakin bertambahnya usia bayi (Gambar 2). Kelompok tanpa fortifikasi mulai mengalami penyimpangan dari kedua kurva referensi pada umur 4 bulan. Sedangkan pada bayi laki-laki kelompok fortifikasi kurva pertambahan panjang badan hampir sama dengan kurva rujukan sampai usia bayi 6 bulan.

Dalam penelitian ini juga ditemukan bahwa pengenalan MP-ASI pada bayi sebelum usia 4 bulan berdampak pada dibanding bayi yang pengenalan MP-ASI dilakukan sesudah usia 4 bulan. Pada bayi yang diperkenalkan MP-ASI sebelum 4 bulan, ditemukan 77,2 persen mengalami pertumbuhan linier $\leq 17,5 \mathrm{~cm}$, sebaliknya bayi yang diperkenalkan MP-ASI sesudah 4 bulan, 72,2 persen mengalami pertumbuhan linier $>17,5 \mathrm{~cm}$. Pertumbuhan linier rata-rata bayi pada usia 6 bulan berdasarkan rujukan $^{(22)}$ adalah $17,15 \mathrm{~cm}$.

Hasil uji Ancova menunjukkan nilai Zskor PB/U antara perlakuan berbeda nyata $(p<0,05)$. Z-skor PB/U pada kelompok tanpa fortifikasi dan kontrol pada umur 6 bulan memburuk dari nilai Z skor PB/U bayi lahir, sebaliknya pada kelompok fortifikasi nilai Zskor membaik (Tabel 2). Pada Gambar 3 dan 4 terlihat, ketiga kelompok perlakuan pada usia satu bulan setelah lahir umumnya mengalami penurunan z-skor PB/U. Hal ini diasumsikan normal, pada umur satu bulan pertama merupakan fase adaptasi bayi terhadap lingkungan baru yaitu di luar janin.

Pada bayi perempuan kelompok tanpa fortifikasi dan kontrol setelah mengalami kenaikan Z skor pada usia 2 bulan, kembali menurun, penurunan yang sangat curam terjadi pada kelompok kontrol. Sebaliknya pada kelompok fortifikasi nilai z-skor PB/U perlahan meningkat hingga usia 6 bulan. Memburuknya nilai Z-skor bayi perempuan untuk kelompok kontrol, semakin jelas dengan bertambahnya usia bayi. Pada kelompok kontrol kejadian stunting telah terjadi pada bayi usia 2 bulan. Presentasi bayi yang mengalami stunting pada kelompok kontrol pada usia 6 bulan sebesar $10 \%$.

Dampak fortifikasi untuk bayi laki-laki pada kelompok fortifikasi tidak seperti bayi perempuan, walaupun pada akhirnya nilai zskor meningkat cukup tinggi setelah berusia 4 bulan.

Hasil analisis regresi berganda menunjukkan bahwa faktor yang nyata $(p<0,05)$ mempengaruhi pertumbuhan linier adalah pemberian pangan fortifikasi, jenis kelamin dan panjang badan lahir. Nilai $\mathrm{R}$ kuadrat yang disesuaikan (Adjusted $R$ Square) adalah 0,382 , yang berarti 38,2 persen nilai pertumbuhan linier bayi dijelaskan oleh pemberian pangan fortifikasi pada ibu waktu hamil, panjang bayi lahir dan jenis kelamin bayi. 
Tinggi lutut tertinggi terdapat pada kelompok fortifikasi dengan efek terkontrol $0,56 \mathrm{~cm}$. Hasil uji Ancova menunjukkan adanya perbedaan yang nyata $(p<0,05)$ terhadap tinggi lutut dan pertambahan tinggi lutut pada usia bayi 6 bulan. Pertambahan tinggi lutut berdasarkan jenis kelamin juga berbeda antara laki-laki dan perempuan. Secara umum pertambahan tinggi lutut lakilaki lebih tinggi dari perempuan. Rata-rata selisih tinggi lutut bayi laki-laki dengan perempuan pada ketiga kelompok adalah $0,53 \mathrm{~cm}$. Pada Gambar 5, menunjukkan pertambahan tinggi lutut dari tertinggi sampai terendah ketiga kelompok berturut-turut adalah kelompok fortifikasi sebesar $4,91 \mathrm{~cm}$, tanpa fortifikasi sebesar $4,21 \mathrm{~cm}$ dan kelompok kontrol sebesar $3,94 \mathrm{~cm}$.

Hasil analisis korelasi dengan Pearson menunjukkan bahwa tinggi lutut berkorelasi positif dengan pertambahan panjang badan $(r=0,743 ; \quad p=0,000)$. Hasil analisis dengan regresi diperoleh persamaan hubungan tinggi lutut dengan panjang badan pada usia 6 bulan, dengan menggunakan tinggi lutut sebagai predictor yaitu ; $Y=26,658+2,208 X$ ( $Y=$ panjang badan dan $X=$ tinggi lutut). Untuk menentukan titik potong (cut off point) tinggi lutut dengan kejadian stunting digunakan dengan analisis regresi. Hasil analisis regresi dengan menggunakan tinggi lutut sebagai predictor terhadap z-Skor PB/U pada usia bayi 6 bulan diperolah persamaan regresi adalah sebagai berikut; $Y=-14,248+$ $0,826 X$, dimana $Y$ sebagai $z$-skore (status gizi) dan $X$ adalah tinggi lutut. Dari persamaan tersebut maka cut off point stunting untuk tinggi lutut tanpa membedakan jenis kelamin bayi pada usia 6 bulan adalah 14,248 cm (Stunting (tinggi lutut): $\leq 14,248$, Normal (tinggi lutut) : > $14,248 \mathrm{~cm})$.

Kadar $\mathrm{Hb}$ kelompok fortifikasi masuk dalam kategori margin artinya secara keseluruhan belum termasuk dalam kategori $\mathrm{Hb}$ kurang (Tabel 4). Karena kadar $\mathrm{Hb}$ pada kelompok fortifikasi tidak ada dibawah 90 $\mathrm{g} / \mathrm{L}$. Hal tersebut sesuai dengan kriteria hemoglobin pada usia 6-23 bulan yang mana dikatakan "kurang" jika $\mathrm{Hb}$ kurang dari 90
g/L, margin antara 90-99 g/L dan cukup 100 $g / L^{(23,24)}$.

\section{BAHASAN}

Pertumbuhan linier bayi dan tinggi lutut dipengaruhi oleh pemberian pangan fortifikasi (biskuit, bihun, susu) pada waktu ibu hamil. Adanya pemberian pangan fortifikasi memberikan pertambahan panjang lebih tinggi $1,53 \mathrm{~cm}$ dibandingkan dengan kelompok tanpa fortifikasi dan 2,18 cm dibandingkan dengan kelompok kontrol. Pemberian pangan fortifikasi pada ibu hamil secara signifikan mempengaruhi pertambahan panjang badan bayi sampai usia 6 bulan. Hal ini diduga ketersedian zat gizi pada bayi dipengaruhi oleh pemberian pangan (susu, biskuit dan bihun) fortifikasi multi gizi mikro (Vitamin $A$, vitamin $C$, seng, besi, folat dan iodium) pada waktu ibu hamil. Pengaruh pemberian pangan ini meningkatkan cadangan gizi keenam fortifikan tersebut yang merupakan zat gizi yang pro terhadap pertumbuhan panjang badan (tulang). Hasil yang hampir sama juga ditemukan pada ibu yang menyusui diberi mie fortifikasi mineral (Ca, I, Se, Zn dan Fe) dan vitamin ( $A, D, E$, folat, B6 dan B12) secara nyata mempengaruhi pertambahan panjang badan bayi $1,48 \mathrm{~cm}$ dibandingkan dengan kelompok kontrol ${ }^{(25)}$.

Penyimpangan pertumbuhan pada penelitian ini ditemukan pada kelompok kontrol pada usia 2 bulan. Hasil penelitian lain menunjukkan bahwa pertumbuhan linier pada dua bulan pertama menunjukkan kondisi yang baik. Sebaliknya setelah umur 2 bulan pertumbuhan berat badan cenderung menurun secara lambat dan pertumbuhan linier turun lebih tajam ${ }^{(4)}$, hasil yang hampir sama menunjukkan retardasi pertumbuhan linier mulai terjadi sebelum atau pada saat usia 3 bulan pertama kehidupan ${ }^{(26)}$.

Proses penyimpangan pertumbuhan linier (growth faltering) pada masa dini yaitu fase bayi sangat tergantung pada zat gizi. Hasil ini membuktikan pengaruh pangan (biskuit, susu dan bihun) yang difortifikasi dengan vitamin $A$, vitamin $C$, folat, besi, seng 
dan iodium, terbukti masih memberikan pengaruh pada bayi sampai 6 bulan pertama. Bukti ini diperkuat oleh efek bersih dari analisis peragam (Ancova) bahwa terdapat perbedaan yang nyata antara ketiga kelompok perlakuan. Ketersediaan cadangan zat gizi ke 6 fortifikan yang merupakan zat gizi yang membantu pertumbuhan dapat memperbaiki pertumbuhan linier pada bayi. Intervensi gizi pada masa kehamilan juga memberikan cadangan atau simpanan zat gizi yang lebih baik pada ibu dan janin, misalnya intervensi besi dapat meningkatkan simpanan besi dalam bentuk laktoferin dalam ASI, ferritin atau haemosiderin dalam hati dan darah, seng dalam bentuk $\alpha$ macroglobulin, asam folat dalam bentuk poliglutamat, dan iodium dalam tiroid dalam bentuk tiroglobulin. Simpanan ini dapat dimanfaatkan bayi dari ASI selama masa menyusui.

Keterlibatan keenam fortifikan dalam pertumbuhan panjang badan/tulang adalah sebagai berikut; lodium adalah komponen penting hormon paratiroid (PTH) yang berfungsi untuk mengontrol pengaktifan vitamin $\mathrm{D}$ menjadi bentuk hormonnya dan kedua hormon tersebut berinteraksi meningkatkan reabsorpsi kalsium (Ca) tulang dan retensi $\mathrm{Ca}$ oleh tubuli ginjal. Hasil penelitian pada tikus membuktikan suplementasi iodium dan selenium dapat memperbaiki berat badan, panjang ekor dan pertumbuhan tulang(27). Selanjutnya kristalkristal hidroksilapatit $\left(3 \mathrm{Ca}_{3}(\mathrm{PO} 4)_{2} \cdot \mathrm{Ca}(\mathrm{OH})_{2}\right)$ dideposit dalam matirks kolagen dan seratserat elastis yang terdiri dari tulang. Pembentukan kolagen dipengaruhi oleh vitamin C dan besi. Vitamin C berperan memelihara status reduksi besi hidroksilasi adalah pembentukan hidroksiprolin dan hidroksilisin selama sintesis kolagen dalam reticulum endoplasmic.

Vitamin A berperan dalam pertumbuhan terutama dalam memodulasi/menyesuaikan pertumbuhan tulang melalui proses remodeling. Vitamin A essensial untuk aktivitas sel-sel dalam tulang rawan epifise yang harus menjadi suatu siklus pertumbuhan normal, maturasi/pendewasaaan dan degenerasi untuk memudahkan pertumbuhan tulang yang normal yang dikontrol pada epifise. Dalam keadaaan defesiensi, resorpsi tulang terhenti, walaupun tidak ada kerusakan dalam proses kalsifikasi. Mineral seng sangat dibutuhkan untuk produksi retinol binding protein (RBP) secara normal. Dimana untuk sekresi hati kedalam plasma, retinal atau retinoid lainnya bersatu dengan RBP. Oleh karena itu defesiensi $\mathrm{Zn}$ akan mengganggu fungsi vitamin $A$ dengan jalan mencegah tingkat pembebasannya secara normal dari penyimpanan dalam hati. Selain itu seng sangat berperan dalam regulasi hormon pertumbuhan (growth hormon, $\mathrm{GH}$ ) dan IGF-1 (insulin-like growth factor-1). Disamping itu seng berperan penting dalam meningkatkan efesiensi utilisasi energi untuk deposisi jaringan dan dalam sisntesis DNA, RNA dan protein yang terjadi dalam pertumbuhan. Mekanisme peranan seng dalam terhadap pertumbuhan linier dan tinggi lutut ini kemungkinan karena seng yang tersedia dapat merangsang pembentukan tulang ${ }^{(28,29,30)}$.

Folat berperan dalam reaksi donasi/penerimaan 1-C dalam metabolisme asam amino, purin dan asam nukleat. Dimana jaringan-jaringan seperti sum-sum tulang yang bersifat hematopoietik (hampir semua tergantung pada proliferasi sel) pertama kali akan dipengaruhi oleh defisiensi THFA (asam tetrahidrofolat) ${ }^{(28,29,30,31)}$.

Selain faktor fortifikan dalam bahan pangan dalam penelitian ini, energi protein dalam pangan itu sendiri juga turut mepengaruhi pertambahan panjang badan bayi dan tinggi lutut pasca kelahiran. Penelitian lain membuktikan bahwa bayi dari ibu yang pada waktu hamil disuplementasi minuman atole (tinggi protein, energi sedang) panjang badanya lebih tinggi (1,44 $\mathrm{cm}, p<0,05)$ dibandingkan dengan panjang badan bayi dari kelompok ibu yang pada waktu hamil disuplementasi minuman fresco (tanpa protein, energi rendah) $)^{(32)}$. Suplemetasi multi gizi dengan seng menunjukkan pertumbuhan tinggi lutut anak lebih tinggi dibandingkan dengan suplementasi seng saja atau multi gizi tanpa 
seng pada anak berumur 6 sampai 9 yang suplementasi selama 10 minggu $^{(33)}$.

Dalam penelitian ini ditemukan bahwa rata-rata panjang badan bayi laki-laki pada usia 6 bulan lebih tinggi $(1,71 \mathrm{~cm})$ dari pada bayi perempuan. Hal ini sesuai dengan rekomendasi ${ }^{(22)}$ dimana panjang badan bayi laki-laki pada usia 6 bulan lebih tinggi (1,9 $\mathrm{cm})$ dari pada bayi perempuan. Peningkatan pertumbuhan panjang badan bayi lebih kuat pengaruhnya pada bayi yang relatif lebih pendek/kurang gizi ketika lahir dibandingkan dengan yang panjang badanya lebih tinggi/cukup gizi. Hal ini diduga disebabkan oleh bayi yang lebih pendek memiliki kecenderungan untuk mengejar pertumbuhannya (catch up growth) setelah lahir. Hasil penelitian yang sama juga ditemukan dengan suplementasi multi gizi mikro selama kehamilan dalam peningkatan pertumbuhan bayi tidak merata pada semua bayi, tetapi lebih kuat pengaruhnya pada bayi yang relatif kurang gizi ketika lahir dibandingkan dengan yang cukup gizi ${ }^{(34)}$. Terdapat dua titik penting bagaimana terjadi kejar tumbuh dari anak yang gizi kurang setelah diperbaiki gizinya yaitu :(1) pertambahan panjang badan berkorelasi negatif dengan panjang badan lahir, sehingga anak-anak stunted akan bertumbuh lebih cepat, dan (2) pertumbuhan linier anakanak umumnya baru mulai setelah berat badan mencapai setidaknya $85 \%$ berat badan terhadap tinggi badan yang diharapkan ${ }^{(35)}$.

Pangan fortifikasi pada penelitian ini lebih pada menahan laju penurunan $\mathrm{Hb}$ bayi sampai usia bayi 6 bulan. Dimana pada kelompok tanpa fortifikasi dan kontrol kadar $\mathrm{Hb}$ pada bayi usia 6 bulan sudah ada dibawah 90,0g/L bahkan pada kelompok kontrol.bayi ada yang $\mathrm{Hb}$-nya 70,6 g/L. Hasil ini sesuai dengan penelitian awal pada ibu bahwa pemberian pangan fortifikasi lebih pada mempertahankan kadar $\mathrm{Hb}$ pada ibu. Dimana prevalensi anemia pada ibu setelah intervensi meningkat 5,4 persen, kelompok tanpa fortifikasi 33,2 persen, dan kontrol 35,4 persen ${ }^{(36)}$, dengan demikian pemberian pangan fortifikasi pada ibu dapat menahan laju peningkatan prevalensi anemia ibu dan bayi sampai pada umur 6 bulan.

Status besi ibu selama hamil berpengaruh terhadap simpanan besi bayi selama beberapa bulan setelah melahirkan. Studi suplementasi besi terhadap ibu hamil di Perancis menyatakan bahwa status besi ibu selama hamil berhubungan dengan status besi bayi pada usia 2 bulan ${ }^{(37)}$. Besi dibutuhkan dalam sirkulasi sebagai komponen $\mathrm{Hb}$ yang terlibat dalam pengangkutan oksigen. Penurunan sel darah merah dan penurunan aktivitas eryhtropoietic adalah hasil dari penurunan metabolisme jaringan, yang berhubungan dengan pernanan besi sebagai kofaktor essensial metabolik. Selain itu besi juga dibutuhkan dalam jumlah sedikit (kira-kira $300 \mathrm{mg}$ ) erat hubunganya dengan beberapa enzim, terutama heme yang mengandung sitokrom dan dalam kompleks Fe-S-protein dalam transpor elektron dan oksidasi fosforilasi dalam sel disamping enzim-enzim hati, katalase dan peroksidase ${ }^{(28,29,30,31)}$. Selain faktor pemberian fortifikan besi, seng dalam penelitian ini, faktor pemberian fortifikan vitamin A juga diduga meningkatkan $\mathrm{Hb}$ pada ibu, janin dan bayi. Hasil penelitian terbaru menunjukkan bahwa suplementasi vitamin A (200.000 IU) pada anak-anak meningkatkan hemoglobin dan menurunkan prevalensi anemia dari 54 persen menjadi 38 persen ${ }^{(38)}$.

\section{KESIMPULAN}

\section{Kesimpulan}

Pemberian pangan fortifikasi pada ibu hamil mempengaruhi pertumbuhan linier dan tinggi lutut bayi secara signifikan. Peningkatan pertumbuhan panjang badan bayi lebih kuat pengaruhnya pada bayi yang relatif lebih pendek/kurang gizi ketika lahir dibandingkan dengan yang panjang badanya lebih tinggi/cukup gizi. Pengenalan MP-ASI yang lebih cepat (< 4 bulan) pada bayi, memiliki pertumbuhan linier, status gizi (PB/ U) dan pertambahan tinggi lutut rata-rata yang lebih rendah dibandingkan bayi yang pengenalan MPASI-nya lebih lama. Stunting (5\%) pada bayi teramati pada umur 2 bulan 
yaitu pada kelompok kontrol, kemudian menaik pada usia 6 bulan Stunting menjadi 10 persen. Bayi pada usia 6 bulan yang tinggi lutunya $\leq 14,248 \mathrm{~cm}$ termasuk dalam kategori status gizi stunting

Pangan fortifikasi pada penelitian ini lebih pada menahan laju penurunan $\mathrm{Hb}$ bayi sampai usia bayi 6 bulan. Dimana pada usia bayi 6 bulan kadar $\mathrm{Hb}<90 \mathrm{~g} / \mathrm{L}$ kelompok tanpa fortifikasi $(8,3 \%)$ dan kontrol $(11,11 \%)$ dan kelompok fortifikasi tidak ada (0\%).

\section{Saran}

Perlu adanya penelitian lebih lanjut menganalisis dampak pemberian pangan fortifikasi zat multi gizi mikro pada ibu hamil terhadap pertumbuhan dan perkembangan kognitif pasca predominan ASI (diatas 6 bulan) serta penelitian lebih lanjut tentang hubungan tinggi lutut dengan panjang bandan dan status gizi (Z-skor PB/U) bayi. Karena rendahnya cakupan ASI eksklusif (6 bulan) pada bayi yaitu 3,36 persen maka kepada pemerintah atau LSM (Lembaga Swadaya Masyarakat) perlu melakukan suatu program pendampingan melekat pada ibu menyusui selama 0-6 bulan.

\section{UCAPAN TERIMAKASIH}

Terimakasih disampaikan kepada Seafast Center IPB yang telah memberikan kesempatan pada penulis untuk melakukan penelitian ini. Penelitian ini adalah bagian dari disertasi penulis ${ }^{1}$.

\section{RUJUKAN}

1. Arifeen SE dkk. 2006. Infant grotwh patterns in the slum Dhaka in relation to birth weight intrauterine growth retardation and prematurity. Am J Clin Nutr 72(4): 1010-1017

2. [Depkes RI] Departemen Kesehatan. 2000. Penaggulangan Anak-anak yang Terpuruk Akibat Krisis. Disampaikan pada Konferensi Nasional III Kesejahteraan Anak, 26-28 Oktober, Jakarta.
3. Shrimpton R dkk. 2001. Word timing of growth faltering. implication nutrition intervention. Pediatrics 107: 1-7

4. Satoto. 1990. Pertumbuhan dan Perkembangan Anak. Pengamatan 0-18 bulan di Kecamatan Mlonggo, Kabupaten Jepara, Jawa Tengah. [Disertasi] Semarang: Program Pascarjana, Universitas Diponegoro.

5. Schmidt MK dkk. 2002. Nutritional status and linier growth indonesian infant in west java are determined more by prenatal enviroment than by postnatal factors. J Nutr 132. 22022207

6. [Depkes RI]. 2001. Strategi Nasional Peningkatan Pemberian ASI Tahun 2001-2005. Makalah Disampaikan pada Workshop Peningkatan Pemberian ASI, 8-10 Juli, Jakarta

7. Meinzen-Derr JK dkk. 2006. Risk infant anemia is associated with exclusive breast-feeding and maternal anemia in a Mexican cohort. J Nutr 136: 452-458.

8. Ortega RM dkk. 1997. Vitamin A status during the third trimester of pregnancy in Spanish women : influence on concentration of vitamin a in breast milk. Am J Clin Nutr 66: 564-68.

9. Gibson RA, Neumann MA, Makrides M. 1997. Effect of increasing breast milk decosahexaenoic acid on plasma and erythrocyte phospolipid fatty acid and neural indices of exlusively breast fed infant. Eur J Clin Nutr. 51: 578-584

10. Jarjou LM dkk. 2006. Randomized placebo-controlled calcium supplementation study in pregnant Gambian women: effect on breast milk calcium concentrations and infant birth weight, growth and bone mineral accretion in the first year of life. Am J Clin Nutr 83 (3):657-666

11. Hilson JA, Rasmussen KM, Kjolhede CL. 2006. Excessive weight gain during pregnancy is associated with earlier termination of breast-feeding among white women. J Nutr.136: 140-146 
12. Marquis SG dkk. 1997. Breast milk or animal product foods improve linear growth of Peruvian toddlers consuming marginal diets. Am J Clin Nutr; 66: 1102-1109

13. Simodon dkk. 2001. Breast-feeding is associated with improved growth in length, but not weight, in rural Senegalese toddlers. Am J Clin.Nutr 73: 959-967

14. Ntab B dkk. 2005. A young child feeding index is not associated with either height for age or height velocity in rural Senegalese children. J Nutr. 135: 457464

15. Eckhardt CL dkk. 2001. Full Breastfeeding for at least four months has differential effects on growth before and six months of age among children in Mexican Community. Amerika Sosiety for Clinical Nutrition. USA.

16. Krammer, 1997 diacu dalam Anwar F, Atmojo SM, Mudjanjanto ES, Martianto D. 2003. Pemberian Makanan tambahan (PMT) biskuit dari tepung ikan yang difortifikasi dengan besi untuk penanggulangan anemia pada ibu hamil. Fakultas Pertanian. IPB. Bogor

17. Shaheen R, Francisco A, Arifeen SE, Ekstrom EC, Persson LA. 2006. Effect of prenatal supplementation on birth weight: an observational study from Bangladesh. Am J Clin Nutr 83 (6): 1355-1361

18. Gopalan dkk. 1973 diacu dalam Nguyen TL. 1997. Effects of Vitamin A and Iron Fortified Supplementation Food on Vitamin A and Iron Status of Rural Preschool Children in Vietnam. [Disertation]. Jakarta: Program Pascasarjana Universitas Indonesia.

19. Walker dkk. 1991 diacu dalam Nguyen TL. 1997. Effects of Vitamin A and Iron Fortified Supplementation Food on Vitamin A and Iron Status of Rural Preschool Children in Vietnam. [Disertation]. Jakarta: Program Pascasarjana Universitas Indonesia
20. [BPS] Badan Pusat Statistik. 2003. Analisis Antropometri Balita. Survey Sosial Ekonomi Nasional 2000. Jakarta

21. Kramer MS dkk. 2003. Infant growth and health outcomes associated with 3 compared with 6 months of exclusive breastfeeding. Am J Clin Nutr 78: 291295

22. [WHO] Word Health Organization. 2006. WHO Child Growth Standards. WHO, Geneva

23. Christakis G. 1973. Nutrition assessment in health program. Am J of $P$ health. II (63) Nov.

24. Roedjito D. 1989. Kajian Penelitian Gizi. Medyatama Sarana Perkasa. Jakarta

25. Aritonang E. 2007. Pengaruh pemberian mie instan fortifikasi pad ibu menyusui terhadap kadar zink dan besi ASI serta pertumbuhan linier bayi. [Disertasi]. Bogor: Sekolah Pascasarjana. Institut Pertanian Bogor.

26. Hautvast JL dkk. 2000. Severe Linear growth retardation in rural Zambian children the influence of biological variable. Am J Clin Nutr; 71: 550-9

27. Reyes RG, Egrise D, Boelaert $M$, Goldman S, Meuris S. 2006. lodine defeciancy mitigates growth retardation and osteopenia in selenium-defecient rats. J Nutr 136: 595-600

28. Linder MC, 1992. Biokimia Nutrisi dan Metabolisme, Parakksi A penerjemah; Jakarta: Universitas Indonesia. Terjemahan dari: Nutritional Biochemistry and Metabolism

29. Lehninger AL 1995. Dasar-dasar Biokimia. Volume 1,2,3. Thenawidjaya M, penerjemah; Jakarta: Erlangga. Terjemahan dari: Principles of Biochemistry.

30. Bender DA. 2002. Introduction to Nutrition and Metabolism $3^{\text {rd }}$ edition. Taylor and Francis Ltd. London

31. Koolman RD, Rohm F. 1996. Color and Atlas Biochemistry. Thieme. New York 
32. Stein $A D$, Barnhart $H X$, Hickey $M$, Schoeder DG, Martorell R. 2003. Prospective study of protein-energy supplementation early in life and of growth in the subsequent generation in Guatemala. Am J Clin Nutr 78: 162-167

33. Pendland JG. dkk. A Preliminary report: effect of zinc and micronutrient repletion on growth and neuropsychological function of urban Chinese children $\mathrm{J}$ Am Coll Nutr 16(3): 268-272

34. Sunawang. $2005 . \quad$ Pengaruh Supplementasi Zat Multi Gizi Mikro selama Hamil terhadap Hasil Kehamilan dan Petumbuhan Bayi [Disertasi]. Jakarta: Program Pascasarjana, Universitas Indonesia

35. Waterlow JC. 1994. Relationship of Gain in Height to Weight. Eur J Clin Nutr 48:S72-S74
36. Prihananto V. 2007. Pengaruh Pangan Fortifikasi Multi gizi mikro terhadap Status Gizi ibu hamil dan berat bayi lahir. [Disertasi]. Bogor: Sekolah Pascasarjana, Institut Pertanian Bogor.

37. Allen L, Gillespie S. 2001. What works? A review of the efficacy and effectiveness of nutrition intervention. ACC/SCN. Nutrition Policy Paper No. 15

38. Zimmermann MB dkk. 2006. Vitamin A supplementation in children with poor vitamin $A$ and iron status increases erythropoietin and hemoglobin concentration without changing total body iron. Am J Clin Nutr 84(3): 580586

Tabel 1

Rata-rata pertambahan panjang badan bayi

\begin{tabular}{|l|c|c|c|c|}
\hline \multicolumn{1}{|c|}{ Umur (bulan) } & \multicolumn{1}{|c|}{$\begin{array}{c}\text { Fortifikasi } \\
\mathrm{n}=40\end{array}$} & $\begin{array}{c}\text { Placebo } \\
\mathrm{n}=39\end{array}$ & $\begin{array}{c}\text { Kontrol } \\
\mathrm{n}=40\end{array}$ & $\begin{array}{c}\text { Nilai-p beda antar } \\
\text { kelompok }\end{array}$ \\
\hline Panjang, usia 0 bulan $(\mathrm{cm})$ & $49,42 \pm 1,84$ & $49,61 \pm 1,31$ & $49,08+1,70$ & 0,303 \\
\hline Panjang , usia 6 bulan $(\mathrm{cm})$ & $67,36 \pm 1,80^{\mathrm{a}}$ & $66,02 \pm 2,04^{\mathrm{a}}$ & $64,84 \pm 2,01^{\mathrm{b}}$ & $0,030^{*}$ \\
\hline Tambahan panjang 0-6 bln $(\mathrm{cm})$ & $17,94 \pm 1,83 \mathrm{a}$ & $16,41 \pm 1,41^{\mathrm{b}}$ & $15,76 \pm 1,70^{\mathrm{b}}$ & $0,026^{*}$ \\
\hline
\end{tabular}

Keterangan: ${ }^{a, b}$ Angka yang diikuti oleh huruf yang sama pada baris yang sama menunjukkan tidak adanya perbedaan antar kelompok. Dampak ini sudah dikontrol dengan berat badan awal, panjang badan awal, jenis kelamin, intik energi, protein, pengasuhan tinggi badan ibu dan morbiditas.

Tabel 2.

Rata-rata Z Skor PB/U bayi

\begin{tabular}{|l|l|c|c|c|c|}
\hline \multicolumn{2}{|c|}{$\begin{array}{c}\text { Indikator Antropometri } \\
\text { PB/U(Z-skor) }\end{array}$} & $\begin{array}{c}\text { Fortifikasi } \\
n=40\end{array}$ & $\begin{array}{c}\text { Placebo } \\
n=39\end{array}$ & $\begin{array}{c}\text { Kontrol } \\
n=40\end{array}$ & $\begin{array}{c}\text { Nilai P beda } \\
\text { antar } \\
\text { kelompok }\end{array}$ \\
\hline \multirow{2}{*}{ 0 bulan } & Rata-rata & $-0,04 \pm 0,63$ & $0,02 \pm 0,40$ & $-0,25+0,56$ & 0,495 \\
& Terkecil & $-1,72$ & -1.17 & -2.28 & \\
& Tertinggi & 2,63 & 1.37 & 1.06 & \\
\hline 6 bulan & Rata-rata & $0,18+0,77^{\text {ab }}$ & $-0,28 \pm 0,95^{\text {bc }}$ & $-0,82+0,94^{\mathrm{c}}$ & $0,010^{*}$ \\
& Terkecil & $-1,09$ & $-1,90$ & $-2,59$ & \\
& Tertinggi & 2,40 & 2,18 & 1,85 & \\
\hline Selisih & Rata-rata & $0,50+0,92^{\mathrm{a}}$ & $-0,26+0,88^{\mathrm{ab}}$ & $-0,52+1,16^{\mathrm{b}}$ & $0,022^{*}$ \\
& Terkecil & $-1,62$ & -1.53 & -2.48 & \\
& Tertinggi & 2,63 & 2.24 & 3.38 & \\
\cline { 2 - 5 } & \multicolumn{4}{|c|}{}
\end{tabular}


* Keterangan: ${ }^{a, b}$ Angka yang diikuti oleh huruf yang sama pada baris yang sama menunjukkan tidak adanya perbedaan antar kelompok. Dampak ini sudah dikontrol dengan berat badan awal, panjang badan awal, jenis kelamin, intik energi, protein, pengasuhan tinggi badan ibu dan morbiditas.

Tabel 3

Pertambahan dan tinggi lutut bayi

\begin{tabular}{|l|c|c|c|c|}
\hline \multicolumn{1}{|c|}{ Umur (bulan) } & $\begin{array}{c}\text { Fortifikasi } \\
\mathrm{n}=40\end{array}$ & $\begin{array}{c}\text { Tanpa } \\
\text { Fortifikasi } \\
\mathrm{n}=39\end{array}$ & $\begin{array}{c}\text { Kontrol } \\
\mathrm{n}=40\end{array}$ & $\begin{array}{c}\text { Nilai P beda } \\
\text { antar kelompok }\end{array}$ \\
\hline $\begin{array}{l}\text { Tinggi lutut usia } \\
1 \text { bulan }(\mathrm{cm})\end{array}$ & $12,80 \pm 0,17$ & $12,80 \pm 0,32$ & $12,79 \pm 0,32$ & 0.809 \\
\hline $\begin{array}{l}\text { Tinggi lutut usia } \\
6 \text { bulan }(\mathrm{cm})\end{array}$ & $17,3 \pm 0,68^{\mathrm{a}}$ & $17,07 \pm 0,70^{\mathrm{b}}$ & $16,59 \pm 0,70^{\mathrm{b}}$ & 0.012 \\
\hline $\begin{array}{l}\text { Tambahan Tinggi lutut } \\
1-6 \text { bulan }(\mathrm{cm})\end{array}$ & $4,47 \pm 0,64^{\mathrm{a}}$ & $4,02 \pm 0,71^{\mathrm{b}}$ & $3,80 \pm 0,74^{\mathrm{b}}$ & 0.007 \\
\hline
\end{tabular}

Keterangan: ${ }^{a, b}$ Angka yang diikuti oleh huruf yang sama pada baris yang sama menunjukkan tidak adanya perbedaan antar kelompok. Dampak ini sudah dikontrol dengan berat badan awal, panjang badan awal, tinggi lutut awal, jenis kelamin, intik energi dan protein, pengasuhan dan morbiditi.

Tabel 4

Sebaran hemoglobin bayi

\begin{tabular}{|c|c|c|c|c|}
\hline $\begin{array}{c}\text { Kategori } \\
\mathrm{Hb}(\mathrm{g} / \mathrm{L})\end{array}$ & $\begin{array}{c}\text { Fortifikasi } \\
(\%)\end{array}$ & $\begin{array}{c}\text { Tanpa fortifikasi } \\
(\%)\end{array}$ & $\begin{array}{c}\text { Kontrol } \\
(\%)\end{array}$ & $\begin{array}{c}\text { Total } \\
(\%)\end{array}$ \\
\hline$<80,0$ & 0,0 & 0,0 & 2,8 & 0,9 \\
\hline $80,0-89,0$ & 0,0 & 8,3 & 8,3 & 5,6 \\
\hline $90,0-99,0$ & 5,6 & 16,7 & 16,7 & 13,0 \\
\hline $100,0-109,0$ & 41,6 & 19,4 & 36,1 & 32,4 \\
\hline$\geq 110$ & 52,8 & 55,6 & 36,1 & 48,1 \\
\hline Terendah & $95,7 \mathrm{~g} / \mathrm{L}$ & $83,3 \mathrm{~g} / \mathrm{L}$ & 70,6 & \\
\hline Rata-rata $\mathrm{Hb}$ & $108,1 \pm 6,8 \mathrm{~g} / \mathrm{L}$ & $106,6+11,5 \mathrm{~g} / \mathrm{L}$ & $104,2 \pm 9,1 \mathrm{~g} / \mathrm{L}$ & $106,3 \pm 9,4$ \\
\hline Tertinggi & $120,0 \mathrm{~g} / \mathrm{L}$ & $123,2 \mathrm{~g} / \mathrm{L}$ & $120,3 \mathrm{~g} / \mathrm{L}$ & \\
\hline
\end{tabular}




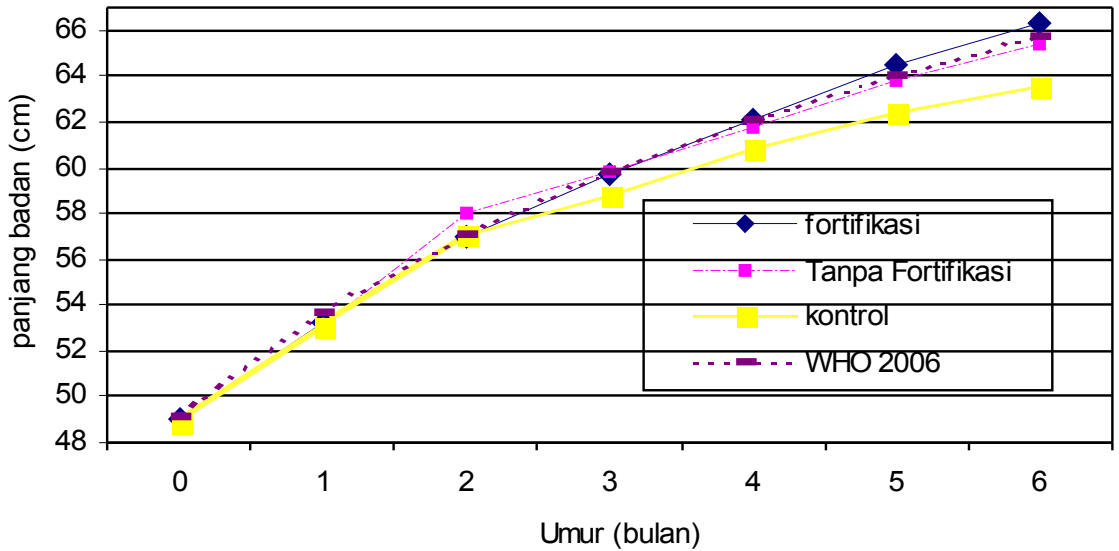

Gambar 1

Rata-rata kenaikan panjang badan bayi perempuan

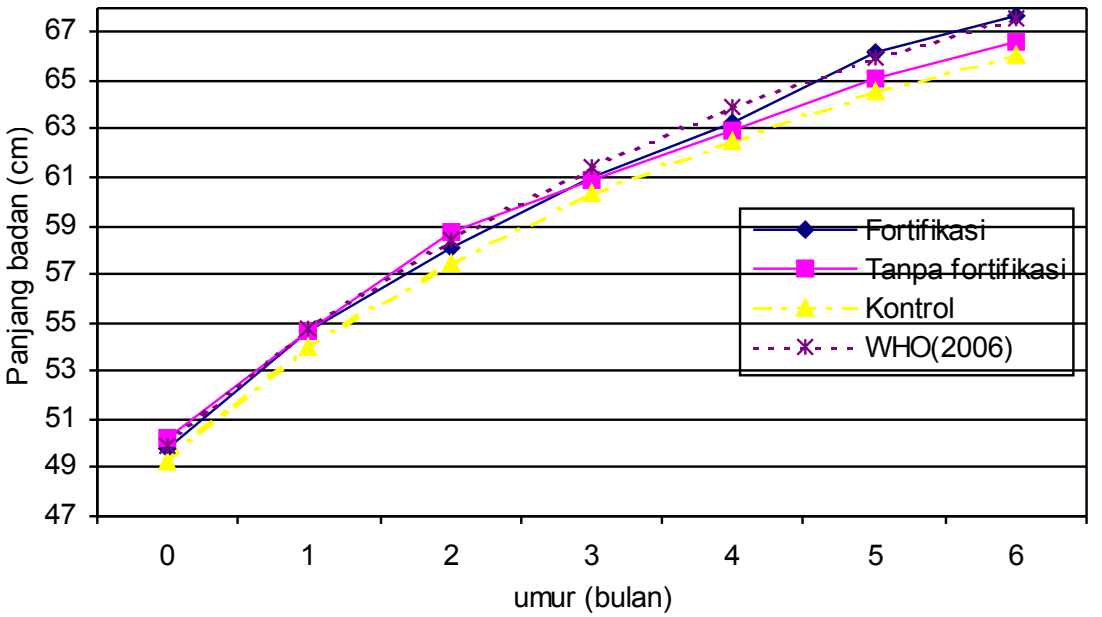

Gambar 2

Rata-rata kenaikan panjang badan bayi laki-laki

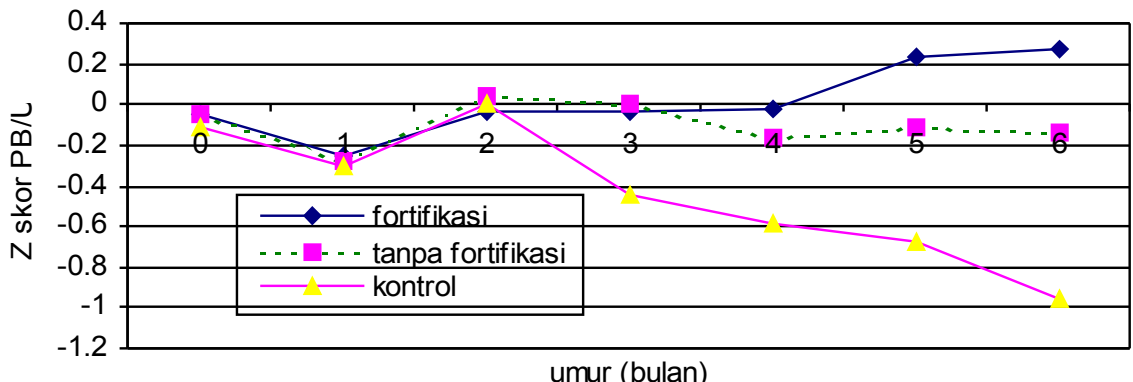

Gambar 3. 
Z skor PB/U bayi Perempuan

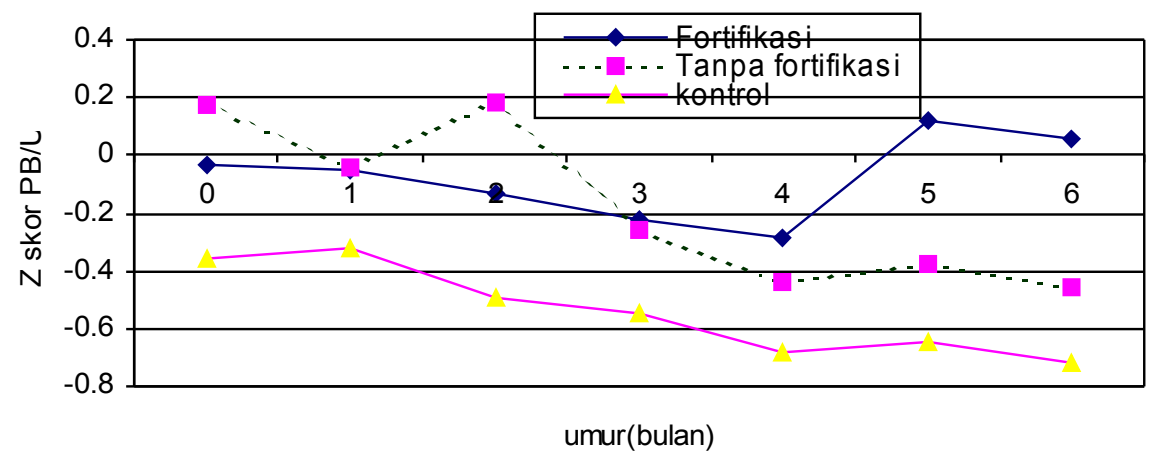

Gambar 4

Z skor PB/U bayi laki-laki

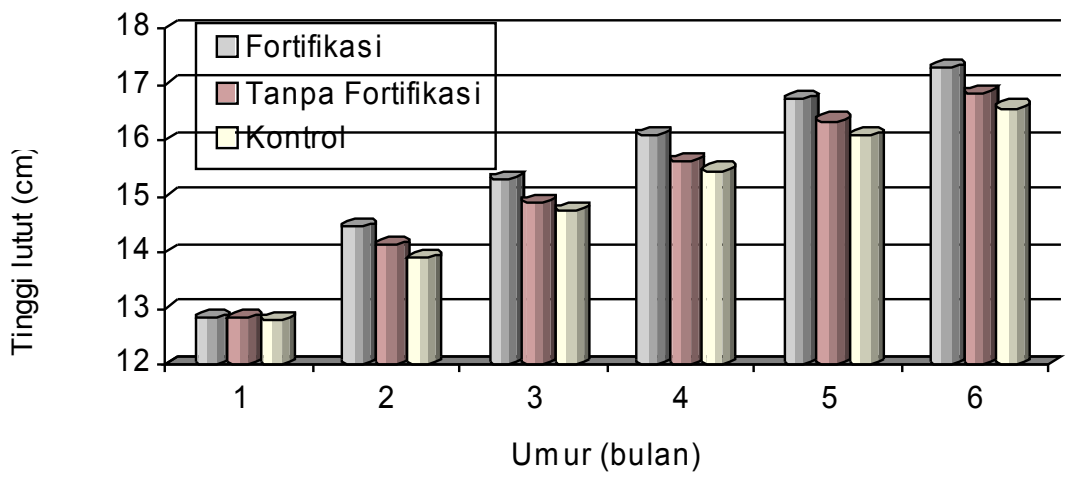

Gambar 5

Tinggi lutut bayi laki-laki dan perempuan 